\title{
Taking General Education Seriously: Expanding The Boundary Of A Principles Of Macroeconomics Course
}

\author{
Patrick B. O’Neill, (E-mail: patrick_oneill@und.nodak.edu), University of North Dakota
}

\begin{abstract}
Does teaching a course that "counts" for general education credit carry with it any responsibilities beyond discipline content? How might you entice students to view a discipline specific course in more general terms? What might be done to link a course in one discipline to courses in related disciplines so that students see connections? These are some of the questions that I have been attempting to answer within the context of a Principles of Macroeconomics course at the University of North Dakota. This paper describes two initiatives undertaken over the past two years. The first initiative occurred during the Spring 2003 semester within two sections of Principles of Macroeconomics. In one section students were given a traditional lecture-based course. In the other section, in addition to lectures, students were asked to read, think about, discuss, and write about how economics relates to other disciplines and how economic thinking might be applied when examining issues beyond economics. The main vehicle used for this latter aspect of the course was to have the students explore the book Dollars and Change: Economics In Context by Louis Putterman. The second initiative took place during the Spring 2004 semester. During this semester, within two sections of Principles of Macroeconomics, all students were asked to read, think about, discuss, and write about general education (liberal learning). The main vehicle used for this initiative was to have the students explore the book A Student's Guide to Liberal Learning by James V. Schall and the description of general education in the University catalog. A detailed description of each of these two initiatives is provided, including copies of assignment sheets and grading rubrics. A discussion of the outcomes of each of these initiatives is presented, from the perspective of the students as well as of the faculty member. The analysis presented is primarily qualitative.
\end{abstract}

\section{INTRODUCTION}

( $\mathrm{n}$ a recent issue of The Chronicle of Higher Education Barry Latzer questions the validity of a distribution-based general education system. ${ }^{1}$ He argues in favor of a common set of courses that would be required of all students. Even if in principle one were to agree with this position, the difficulty of e getting a diverse set of faculty to agree on what such a common core should include seems foreboding. Is there some middle ground that might be found between the common core and the distribution system? Is it possible to take general education seriously within a distribution based system? If yes - what would this entail? Does it mean merely noting that a course "counts" as general education credit and feeling privileged (or put upon) as the instructor thereof? Does it mean consciously doing something about the general education designation? If the latter - what to do? Should the something be discipline specific? If you teach a course in the "venerable Seven Liberal Arts," is it sufficient to provide your students with the best presentation of the subject matter, resting secure in the knowledge that your discipline is a fundamental part of any well educated person? ${ }^{2}$ What if your discipline is not part of the "venerable seven"? Do you then need to do something different - something beyond the mere presentation of the discipline material - in order to make your course a real general education course? Should you entice (coerce) your students to actually think about (or even discuss) what general education means, perhaps thereby causing the students to take ownership of their education? If this latter, how might this be accomplished? These are some of the questions that underlie the curriculum initiatives described in this paper. 


\section{THE CURRICULUM INITIATIVES - AN OVERVIEW}

My discipline is economics. In this paper I describe some ways I have tried to get my students - and myself to take general education seriously within a course that "counts" for general education credit at the University of North Dakota. The course is Principles of Macroeconomics and it "counts" as part of the social science distribution requirement. In addition to the content based distribution requirements, the University has six areas of crossdisciplinary abilities as part of its general education goals. ${ }^{3}$ Included among these cross-disciplinary abilities is the goal of "recognizing relationships." During the Spring 2003 semester I added into the course some assignments that were focused on this goal. My specific purpose was to have the students come away from the course with not only a knowledge of basic macroeconomics, but also a sense of how economics connects (or not) to other disciplines. During the Spring 2004 semester I broadened the scope of the course. The students were given an assignment that required them to contemplate the meaning of liberal learning and compare that to the university's general education goals.

In developing each of these initiatives, two implicit objectives (perhaps better described as implicit constraints) were a part of my thinking process. The first was that the general education piece of the course would necessarily take the form of an additional assignment. This stems from two sources: the fact that Economics is not one of the "venerable seven" and thus simply presenting the content of economics was not sufficient in my mind to qualify as a part of liberal education experience; and my desire to focus not on the disciplinary abilities part of the University general education goals, but rather on the cross-disciplinary abilities. The second objective was the self-imposed constraint that the initiative be based on a book. ${ }^{4}$ This was due to my desire to impel a passion for books within my students. More will be said about these two constraints later in the paper.

\section{FIRST CURRICULUM INITIATIVE: SPRING 2003}

During the Spring 2003 semester I taught two sections of Principles of Macroeconomics. ${ }^{5}$ One section was a bare bones course - lectures and exams based on a standard Macroeconomics textbook. ${ }^{6}$ The other section consisted of the same lectures and exams based on the same standard textbook but also included reading, discussing, and writing about the book Dollars and Change by Louis Putterman (DC). ${ }^{7}$ A copy of the course requirements section of the syllabus for each course, the essay assignments handout, and the essay grading rubric is included in Appendix 1 below.

The purpose of adding the Putterman book was to get the students to think about how economics fits in to the bigger picture of their overall education, to explore how economics is similar to and different from other disciplines, to explore how applying the tools of economics might shed light on some issues that might not otherwise be illuminated.

\section{Assignments and Activities}

The students were required to read, discuss, and write about the book Dollars and Change. We discussed each of the six chapters in class - with one class period allocated to the discussion of each chapter. ${ }^{8}$ The students were required to read the chapter prior to the discussion period. For each chapter the students were required to submit 2-3 questions prior to our in-class discussion. (I supplied all the questions for the first chapter - the student assignment began with the second chapter.) These discussion questions were compiled and handed out to the students during the discussion period. For the discussion period we looked at some of the questions submitted by students and/or questions that I decided we should investigate. The discussions took place in both small groups (3-4 students) and a large group (the entire class). The students were also required to write two short essays on the book. The first essay was to write on something related to the book and/or our discussion sessions. The second essay was to write a review of the book. Both essays were due toward the end of the semester. 


\section{Assessment}

Was the "purpose" of this initiative fulfilled? Yes or no - and how do I know?

Did the students get a sense of how economics fits within their overall education? Evidence from the course suggests that the answer is a qualified yes. The primary evidence for this answer comes from directly questioning the students. The students were asked to rate each of the following three statements on a five point scale: $1=$ strongly agree; 2 = agree; 3 = undecided; 4 = disagree; 5 = strongly disagree.

- $\quad$ Reading Dollars and Change helped me to see relationships (inter-relatedness or inter-connections) between economics and other subject areas.

- Discussing Dollars and Change helped me to see relationships (inter-relatedness or inter-connections) between economics and other subject areas.

- Writing about Dollars and Change helped me to see relationships (inter-relatedness or inter-connections) between economics and other subject areas.

The percentage of students who responded with a 1 or a 2 to these statements is 75,85 , and 64 respectively. ${ }^{9}$ This is a large proportion of students to reach in a course that is taken by most students as a requirement outside of their major. Still, a significant number of students weren't convinced of the value of these activities.

\section{Am I happy with the outcome?}

Not really. My dissatisfaction stems from several sources. First, the attendance during the discussion sessions was not particularly good. After reflecting on this it occurred to me that this was likely because the in-class discussion part of the assignment did not "count" in the grade for the course. Secondly, in looking at the responses to the "overall impression" question on the student course evaluations - the responses for the section of the course within which I had the students grapple with Dollars and Change were the lowest scores I have received in 16 years of teaching this course. Lastly, the Dollars and Change book was not as ideally suited to achieving the goals of the initiative as I had at first thought. Much of the book attempts to put "economics in context" by describing the history and evolution of the discipline rather than by relating economics or economic analysis to other disciplines. This latter is primarily limited to Chapter 6 of the book. ${ }^{10}$

Perhaps an obvious next step would be to limit the "general education assignment" to Chapter 6 of Dollars and Change. This would allow for the goal of making connections between economics and other disciplines to be addressed while avoiding the content overlap that exists between the main text and some of the earlier chapters of Dollars and Change. However doing so would not allow for the achievement of the "implicit goal" of developing in the students a passion for books. Thus the next time I taught the course I incorporated a different supplemental book and as a result, the nature of the initiative changed.

\section{SECOND CURRICULUM INITIATIVE: SPRING 2004}

During the Spring 2004 semester I taught two sections of Principles of Macroeconomics. ${ }^{11}$ In both sections of the course I lectured on and examined students on the content of a standard Macroeconomics textbook. ${ }^{12}$ The students were also required to read, discuss and write about some additional material:

- $\quad$ The book A Student's Guide to Liberal Learning by James V. Schall (LL)

- $\quad$ The general education requirements listed in the University Catalog ${ }^{13}$

A copy of the course requirements section of the syllabus and the essay assignments handout is included in Appendix 2 below. ${ }^{14}$ 
The purpose of this initiative was to get students to think "outside the course." I wanted the students to reflect on the purpose of their education, to explore what it means to have a liberal education, to see if that is what is being provided via their general education requirements. ${ }^{15}$

\section{Assignments and Activities}

The assignment consisted of reading, discussing and writing about material on liberal learning. The students were asked to write a one-page essay comparing and contrasting the description of liberal learning in LL with the general education goals in the University catalog. One class period was allocated to discuss the essay. The discussion took place in both small groups (3-4 students) and a large group (the entire class).

\section{Assessment}

$$
\text { Was the "purpose" of this initiative fulfilled? Yes or no - and how do I know? }{ }^{16}
$$

Did the students actually think about the nature or purpose of their overall university education? I think the honest answer to this is both yes and no. (Does this mean the most honest answer is maybe - or perhaps I don't know?) The students (at least most of them) did reflect on their overall university education, but it was not as apparent that the students were developing discerning minds.

This answer is based on both my reflections upon the student essays and the in-class discussion session as well as on data collected directly from the students. As I read the student essays in which they compared the notion of liberal learning from Schall's book with that presented in the university catalog, it was apparent that most of the students had put some thought into their essays - however in most cases not as much depth of thought as I was hoping for. The in-class discussion periods did generate some enthusiastic responses. Indeed several students expressed strong opinions (some favorable and some unfavorable) on various parts of the Schall essay. This indicated to me that at least some of the students had possession of a questioning mind. However not everyone was actively participating in those discussions.

My sense of the limited success of this initiative is verified by the responses from the students on an end-ofcourse evaluation instrument. The students were asked to "Describe one thing you learned from reading and/or writing about $A$ Student's Guide to Liberal Learning." The most common response was that students mentioned either or both of the two things Schall says are needed if students are to become liberal learners - namely self discipline and a personal library. This suggests that many students took away from the assignment an easy to recall tidbit rather than a deeper sense of the nature or purpose of their own education. While this answer was the most common, the range of responses was quite broad. The following samples illustrate that range:

I learned that there is more than one person out there that knows what is going on in this world. The concepts were so much fun to read and learn about. For once I actually enjoyed reading.

I learned that education should be a life-long process, and requires more than just showing up for class and studying for tests. It made me think about the way I look at school and what I've learned and how I learned it....Although I have not changed my learning habits.

I learned that even though I don't agree with the content of a book, it can still be something worth reading. I do not agree with Schall, but his book made me think about and appreciate my university education.

I did not learn anything particularly worthwhile from this book.

I was less than enthused when I learned I had to write essays on a book unrelated to class. I thought 'this is Macro not English.' I was not motivated to read this book and so I did not. However one of the skills I have picked up in college is the fine art of BS, which allowed me to write my essays. 
These few sample responses suggest that some students did undertake serious reflection about their education, but also that not all of the students were particularly fond of this assignment. I discuss this latter point in more detail below.

Am I happy with the outcome?

I am reasonably happy with the outcome. In addition to the evaluation question described above, the students were asked "Would you recommend that I require $A$ Student's Guide to Liberal Learning the next time I teach this class? Why or why not?" The results:

\begin{tabular}{|c|c|c|}
\hline Response & Number $^{17}$ & Percent \\
\hline$\overline{\text { Yes }}$ & $\overline{67}$ & $65 \%$ \\
\hline No & 23 & $22 \%$ \\
\hline Uncertain & 13 & $13 \%$ \\
\hline
\end{tabular}

A sampling of the reasons given for the responses:

Reasons for NO:

- $\quad$ Too complicated - hard to understand - a book for philosophy students not economics students

- This is economics not English

- $\quad$ Waste of time because majority of students did not take it seriously

- $\quad$ The book is (really, incredibly) boring

- It was busy work that had nothing to do with economics

\section{Reasons for YES:}

- $\quad$ Nice break from (change of pace from) economics material

- $\quad$ Allows for being graded on something in addition to (other than) tests - specifically essays

- $\quad$ It is a good way to earn points - not as difficult as the economics material

- It is good because it made us think - especially about learning and our education

- We had to suffer through it so future students should too

- I I think what he writes about could be applied to almost any class

- I I think this book highlights some important aspects of becoming a better student

- $\quad$ Yes, 9 out of 10 times, I believe at least $1 / 2$ the students who read this book seriously will greatly benefit

While nearly $2 / 3$ of the students recommend that the book be used in the future, some of the reasons given are less than heartwarming. Some students clearly valued the experience of thinking about their overall education, but many viewed the assignments as merely an easy way to get points. Of particular importance to the issue of taking general education seriously are the (not infrequent) comments that none of this belongs in a course on economics. This indicates an attitude of compartmentalized learning among many students with which we are all too familiar. Indeed I suspect we can think of not a few of our colleagues who have a similar attitude about education. Reflecting on these student responses brings to mind several questions. What threshold percentage of responses saying "yes - use the book again" is appropriate to allow me to feel comfortable (confident) in repeating this assignment in future classes? Is student satisfaction (or recommendation) even appropriate as a metric by which to assess this activity? Should we as instructors do what we feel is in the best interest of our students - whether they like it or not? While there are perhaps no "correct" answers to these questions I offer what I consider "reasonable responses" to them. If a majority of students (i.e. at least 51\%) are in favor of repeating an assignment, I think you have a sufficient mandate from which to view it as worth repeating. However, I also feel that student satisfaction with an assignment should not be given too much weight in an instructor's decision calculus. All of these data suggest to me that the Schall book provided a useful vehicle for getting at the issues of interest in this initiative. 
One additional piece of data deserves comment. I noted above that the student responses to the "overall impression" question on the course evaluations for the Spring 2003 initiative were the poorest results I have ever received for this course. The responses from the students on the overall evaluation question from the Spring 2004 initiative are consistent with my typical results from the 15 years prior to undertaking either of these initiatives. These results suggest that the Spring 2004 initiative was a small enough portion of the course that even those who were unhappy with it were still pleased with the course overall.

\section{LESSONS LEARNED}

As is often the case with curriculum initiatives - the lessons learned seem obvious when looking back on the experience. They did not appear obvious to me at the time I was conducting them.

\section{Plan In Advance}

I have different and not completely compatible student response data from each initiative - this obviously makes it hard to compare and draw conclusions. ${ }^{18}$ Plan ahead for the data that you want - plan carefully - look at what others are doing - and learn from it. I have much better data from the Spring 2003 initiative because it was a funded project as part of a grant from the Bush Foundation - so I was forced to be more precise in both development and implementation. The Spring 2004 initiative was undertaken with less forethought - and the (lack of) data available for analysis reflects this.

\section{Students Don't Like "Extra Work"}

During the Spring 2003 initiative some students discovered that the "other section" of my Principles of Macroeconomics course did not have to read, discuss, or write about Dollars and Change - and several asked if they could switch to that other section. I denied this request. During the Spring 2004 initiative some students noticed that the other instructors of Principles of Macroeconomics courses did not require A Student's Guide to Liberal Learning and wondered why they should have to endure it. In each case, the students were not always placated when informed that they were getting "extra learning opportunities" without having to pay any extra tuition. The more carefully (clearly) you can explain the rationale of the "extra learning experience" to the students the more you will minimize (but not likely eliminate) comments of this sort.

\section{Students Are Resistant To Thinking Outside The Course}

This was especially evident in the Spring 2004 initiative as numerous students pointed out that a book on liberal learning might be used in an English class but should not be used in a course in Economics. This observation (complaint) might never be able to be completely expunged - but I think we should try to do so. How might this be accomplished? Providing students with a rationale for what is being done, describing why you feel it is important, and explaining how the project/assignment(s) will be of benefit to them will all help to motivate many (although unlikely all) of the students.

\section{Instructors Need To Discover (And Consider Relaxing) Implicit Constraints}

As noted above, among the implicit constraints of these initiatives was that the general education portion of the course needed to involve the reading of an additional book. Also included in the list of implicit constraints was the desire to have students develop a passion for books. It is likely that these constraints contributed to the student view that "extra work" beyond the core course content was required. Incorporating a discussion of general education within a course that receives general education credit can certainly be done without the use of an additional book. Doing so would require relaxing the implicit constraints, which is only possible if those constraints are made explicit, especially to oneself. This suggests the need to discuss assignments with colleagues prior to, rather than after, you try them out on students. 


\section{CONCLUDING REMARKS}

If one is serious about general education and attempts to stretch the boundary of a course that receives general education credit, it seems appropriate to ask some tough questions. What is the appropriate boundary? How much can the boundary be stretched? Who should decide when the boundary has been stretched too far - students or the teacher?

The initiatives described in this paper present some tentative answers to these questions in the context of a particular course: Principles of Macroeconomics. Student feedback suggests that the two initiatives described in this paper seem to straddle the appropriate boundary. For them, the assignments related to Dollars and Change are on the "acceptable" side of the boundary; the assignments related to A Student's Guide to Liberal Learning are on the "unacceptable" side. But should student opinion be the deciding factor? Perhaps not. I find myself recalling the wisdom of novelist Flannery O'Connor (emphasis added): ${ }^{19}$

The ... teacher will be fulfilling his responsibility if he furnishes the student a guided opportunity...And if the student finds this is not to his taste? Well, that is regrettable. Most regrettable. His taste should not be consulted; it is being formed.

\section{ENDNOTE}

1. Barry Latzer, Common Knowledge: the Purpose of General Education The Chronicle of Higher Education, October 8, 2004, page B20.

2. The "Venerable Seven Liberal Arts" consist of the Trivium (Grammar, Rhetoric, Logic) and the Quadrivium (Astronomy, Music, Geometry, Arithmetic). See Tracy Lee Simmons, Climbing Parnassus, ISI Books, 2002, page 49.

3. In addition to the distribution based course requirements, the 2001-2003 Academic Catalog lists six goals under the heading Cross-Disciplinary Abilities: critical thinking, communication, creative thinking, recognizing relationships, recognizing and evaluating choices, and world cultures.

4. Indeed an astute colleague has suggested this paper should be subtitled "The Quest for the Book." I thank Libby Rankin for this and numerous other helpful suggestions. Most of her suggestions have been incorporated, resulting in a much more cogent examination of the initiatives than would otherwise have been the case.

5. There were 18 students enrolled in the "bare bones" section and 41 in the other section.

6. The text used was Macroeconomics, 4e, David C. Colander, Irwin/McGraw-Hill, 2001.

7. Louis Putterman, Dollars and Change: Economics in Context, Yale University Press, 2001.

8. The six chapter titles are as follows: Chapter 1 - The Industrial Economies in Perspective, Chapter 2 Economic Thought in Perspective, Chapter 3 - Economic Systems, Chapter 4 - The Less Developed World and Its Prospects, Chapter 5 - Economics and Justice, and Chapter 6 - The Economy and Quality of Life.

9. Of the 41 students enrolled in the course, 33 responded.

10. Indeed when I asked the students if they would recommend that I use Dollars and Change the next time I teach the course, only $52 \%$ said yes. What to make of this percentage? I speak to this issue in the discussion of the Spring 2004 initiative below.

11. There were 64 students enrolled in one section and 69 students in the other section.

12. The text used was Macroeconomics, 5e, David C. Colander, Irwin/McGraw Hill, 2004.

13. A Student's Guide to Liberal Learning by James V. Schall, ISI Books, 2000. This book is available both in hard copy and as a pdf file at http://www.isi.org/college_guide/student_guides.html. James V. Schall is a professor of government at Georgetown University. He has written extensively on the nature and purpose of a liberal education. This particular book was chosen because it presents a specific vision of liberal learning that I felt would likely generate animated reaction from students. Schall's view of liberal learning is quite traditional. Schall describes the student who acquires a liberal education as one who has developed a questioning mind, a discerning mind. That is, a mind that questions the veracity of what it is being told; a mind that is able to discern the good from the bad, to discern the truth of things, to discern, as Schall states it, what is. Schall expresses a belief that not too many universities today provide this type of liberal education. 
In addition, in the book Schall includes many reading lists in an effort to encourage students to become passionate about books and reading. The University general education goals are from pages 25-6 of the 20012003 Academic Catalog and are available as indicated in note 3 above.

14. It should be noted that the students were required to write three essays. All three essay assignments are described in Appendix 2 below. Only essay assignment \#2 is discussed here. The other essays provided some interesting information but are outside the scope of this paper.

15. There is certainly no guarantee that simply satisfying a set of discipline distribution requirements will result in a student with a discerning mind. However cross-disciplinary general education goals, if achieved, might produce such a student. I wanted to find out if the students felt that their education was providing them with a discerning mind.

16. The assessment of this initiative is more qualitative than that of the prior initiative. This is the case because there was less pre-planning for this initiative and so less data are available to analyze. I return to this in the Lesson Learned section below.

17. Of the 133 students enrolled in the course, 103 responded to this question.

18. In particular, I do not have any data from the Spring 2004 initiative that compares to the Likert scale data reported about the Spring 2003 initiative.

19. Flannery O'Connor, Total Effect and the Eighth Grade in Mystery and Manners: Occasional Prose, FSG, New York, 2000, page 140. While O'Connor was specifically writing about the high school English teacher, the wisdom is applicable to all teachers. 


\footnotetext{
${ }^{1}$ Barry Latzer, "Common Knowledge: the Purpose of General Education" The Chronicle of Higher Education, October 8, 2004, page B20.

${ }^{2}$ The "venerable Seven Liberal Arts" consist of the Trivium (Grammar, Rhetoric, Logic) and the Quadrivium (Astronomy, Music, Geometry, Arithmetic). See Tracy Lee Simmons, Climbing Parnassus, ISI Books, 2002, page 49.

${ }^{3}$ In addition to the distribution based course requirements, the 2001-2003 Academic Catalog lists six goals under the heading Cross-Disciplinary Abilities:

$\begin{array}{ll}\text { - } & \text { Critical Thinking } \\ \text { - } & \text { Communication } \\ \text { - } & \text { Creative Thinking } \\ \text { - } & \text { Recognizing Relationships } \\ \text { - } & \text { World Cultures }\end{array}$
}

These goals are described in more detail on pages 25-6 of the catalog. The details are available on the web at http://www.und.nodak.edu/dept/registrar/catalogs/Year0103/ugdept/purpose.html.

${ }^{4}$ Indeed an astute colleague has suggested this paper should be subtitled "The Quest for the Book." I thank Libby Rankin for this and numerous other helpful suggestions. Most of her suggestions have been incorporated, resulting in a much more cogent examination of the initiatives than would otherwise have been the case.

${ }^{5}$ There were 18 students enrolled in the "bare bones" section and 41 in the other section.

${ }^{6}$ The text used was Macroeconomics, 4e, David C. Colander, Irwin/McGraw-Hill, 2001.

${ }^{7}$ Louis Putterman, Dollars and Change: Economics in Context, Yale University Press, 2001.

${ }^{8}$ The six chapter titles are as follows:

- Chapter 1 The Industrial Economies in Perspective

- Chapter 2 Economic Thought in Perspective

- Chapter 3 Economic Systems

- Chapter 4 The Less Developed World and Its Prospects

- $\quad$ Chapter 5 Economics and Justice

- Chapter 6 The Economy and Quality of Life

${ }^{9}$ Of the 41 students enrolled in the course, 33 responded.

${ }^{10}$ Indeed when I asked the students if they would recommend that I use Dollars and Change the next time I teach the course, only $52 \%$ said yes. What to make of this percentage? I speak to this issue in the discussion of the Spring 2004 initiative below.

${ }^{11}$ There were 64 students enrolled in one section and 69 students in the other section.

${ }^{12}$ The text used was Macroeconomics, 5e, David C. Colander, Irwin/McGraw Hill, 2004.

${ }^{13}$ A Student's Guide to Liberal Learning by James V. Schall, ISI Books, 2000. This book is available both in hard copy and as a pdf file at http://www.isi.org/college_guide/student_guides.html. James V. Schall is a professor of government at Georgetown University. He has written extensively on the nature and purpose of a liberal education. This particular book was chosen because it presents a specific vision of liberal learning that I felt would likely generate animated reaction from students. Schall's view of 
liberal learning is quite traditional. Schall describes the student who acquires a liberal education as one who has developed a questioning mind, a discerning mind. That is, a mind that questions the veracity of what it is being told; a mind that is able to discern the good from the bad, to discern the truth of things, to discern, as Schall states it, what is. Schall expresses a belief that not too many universities today provide this type of liberal education. In addition, in the book Schall includes many reading lists in an effort to encourage students to become passionate about books and reading. The University general education goals are from pages 25-6 of the 2001-2003 Academic Catalog and are available as indicated in note 3 above.

${ }^{14}$ It should be noted that the students were required to write three essays. All three essay assignments are described in Appendix 2 below. Only essay assignment \#2 is discussed here. The other essays provided some interesting information but are outside the scope of this paper.

15 There is certainly no guarantee that simply satisfying a set of discipline distribution requirements will result in a student with a discerning mind. However cross-disciplinary general education goals, if achieved, might produce such a student. I wanted to find out if the students felt that their education was providing them with a discerning mind.

${ }^{16}$ The assessment of this initiative is more qualitative than that of the prior initiative. This is the case because there was less preplanning for this initiative and so less data are available to analyze. I return to this in the Lesson Learned section below.

17 Of the 133 students enrolled in the course, 103 responded to this question.

${ }^{18}$ In particular, I do not have any data from the Spring 2004 initiative that compares to the Likert scale data reported about the Spring 2003 initiative.

${ }^{19}$ Flannery O'Connor, “Total Effect and the Eighth Grade” in Mystery and Manners: Occasional Prose, FSG, New York, 2000, page 140. While O'Connor was specifically writing about the high school English teacher, the wisdom is applicable to all teachers. 